\title{
Judge's Dilemma In Granting Underage Marriage Dispensation Request
}

\author{
Muhammad Akbar Fhad Syahril \\ Amsir Law School, Parepare \\ email: akbar9.a9@gmail.com.com
}

\begin{abstract}
This study aims to analyze the consideration of judges in granting applications for dispensation of underage marriages and factors that influence the administration of marital dispensation. The type of research used is normative juridical research, the source of data from literature research and literature studies from several books and scientific works, using a case approach. The results of this study showed that the judge referred to Law No. 1 of 1974, Compilation of Islamic Law, Law No. 23 of 2002, and Fiqqiyah Rules. Factors that affect her in addition to getting pregnant out of wedlock are also still low in benefits and deficiencies, economic factors, and education.
\end{abstract}

Keywords: Judge Consideration, Marital Dispensation, and Underage Marriage.

\section{Introduction}

Marriage is defined by aqad or covenant, which means to allow intercourse using the word nakaha or zawaja. ${ }^{1}$ Marriage is one of the sunnahtullah that is common to all creatures of Allah, both in humans, animals and plants. It is also natural for man to continue throughout the history of human life. The main purpose of marriage is to foster an eternal and happy family life between husband and wife in order to continue their offspring. Without marriage, human survival will surely be extinct and the history of human life will stop. ${ }^{2}$

In the discourse of figh is not found a method that limits the age of marriage. And the fuqoha only stated that the benchmark of the ability of underage women to be cared for is the need for readiness to perform sexual activities (wath'iy) along with all its consequents, such as pregnancy, childbirth, and breastfeeding, which is characterized by the coming of puberty. In accordance with the words of Alqorori until the little girl achieves perfection and physical maturity. ${ }^{3}$

${ }_{2}^{1}$ Amir Syarifuddin, Garis-Garis Besar Fiqh, Jakarta (Predana Media, 2005).

${ }^{2}$ Muh Akbar Fhad Syahril, 'The Effectiveness Of The Annulment Of Marriage Due To Impersonation And Its Legal Consequence', IOSR Journal Of Humanities And Social Science (IOSRJHSS, 23.2 (2018), 2279-0845 <https://doi.org/10.9790/0837-2302023944>.

${ }^{3}$ A dan; Khoirotul Waqi'ah Mahfudin, 'Pernikahan Dini Dan Pengaruhnya Terhadap Keluarga Di Kabupaten Sumenep Jawa Timur', Hukum Keluarga Islam, 1.April (2016), 33-49 $<$ http://journal.unipdu.ac.id:8080/index.php/jhki/article/view/608>. 
Age or maturity does not include the terms and conditions of marriage. A marriage is considered valid if it meets the requirements and gets along well. The scholars differed on the age limit factor of maturity. This is a very important factor because underage marriages often occur in girls, while the marriage of minors is less. If Islamic law does not provide concrete restrictions on the minimum age of marriage does not mean that Islam absolutely allows underage marriage. ${ }^{4}$

The rationale for the absence of age restrictions for couples who are going to marry may be in accordance with the views of the people at that time about the nature of marriage. According to the view at that time, marriage is not seen in terms of sex, but in terms of its influence in creating relationships (mushaharah). The Prophet married Aisya at the age of six among his motives, namely for the freedom of Abu Bakar al-Shiddiq to enter the Prophet's household. ${ }^{5}$

In addition, the Government has issued Law Number 1 of 1974 on Marriage, this law contains a very broad content, namely regulating the issue of marriage, demarcation, the position of children, rights and obligations between parents and children, and also regulates the issue of guardianship and regulates the proof of the origin of the child. The Marriage Act, it is also clearly regulated regarding the basic provisions as well as the terms of marriage. If the conditions of marriage have been met then the marriage can be declared as a valid marriage.

Government policy in setting the minimum age limit for marriage has certainly gone through a process and various considerations. It is intended that both parties are fully prepared and mature from the physical, psychic, and mental aspects. ${ }^{6}$ One of the conditions in the Marriage Law is to regulate the minimum age limit in the conduct of marriage. In the Marriage Law, regulated in it on the principle of prospective husband and wife is required to be ready for their bodies and bodies to be able to conduct marriage, in order to realize the purpose of marriage well, without having to end up in the Court of Religion, and can obtain good and healthy offspring.

In addition, close marriage is very closely related to population problems, because the minimum age limit for a woman to mate, can lead to a higher birth rate if

\footnotetext{
${ }^{4}$ Umar Said, Hukum Islam Di Indonesia Tentang Perkawinan (Surabaya: Cempaka, 2000).

${ }^{5}$ Amir Syarifuddin, Hukum Perkawinan Islam Di Indonesia, 2006.

${ }^{6}$ Dwi Rifiani, 'Pernikahan Dini Dalam Perspektif Hukum Islam', Journal De Jure, 3.2 (2011) $<$ Https://Doi.Org/10.18860/J-Fsh.V3i2.2144>.
} 
it is compared to the higher age limit. Therefore, the terms of the lowest age limit are set in the conduct of marriage.

Underage marriages that occur in society are caused by various problems including religious, economic and social issues. Religious problems related to the religious practice of a person, among religious believers married minors as an option to avoid sin, fear of committing adultery, follow the Sunnah of the Apostle, expect Blessing and so on. Economic motivation with marriage expects to be lifted, the family economy increases, eases the burden on parents and so on. Social problems such as being proud of men can marry young girls, have inner satisfaction and so on. $^{7}$

Not until there, for the poor, marrying their children is a release of burden. Where parents will feel the burden of their lives is reduced because the child is already the responsibility of her husband. The sooner the girls marry the better for their lives due to the lightweight of the burden of life they bear. ${ }^{8}$

This research is taken from some examples of previous research as a guide or examples for research conducted today. Taken in the form of journals on the problem of underage marriage in the paper discussing underage marriage in Wonoayu is an exception because society in general married after the age of 20 years and above. Underage marriages are usually performed abruptly so that there is no marriage process as is the tradition of marriage, such as walimahan.

The marriage took place simply, quite done in Office of Religious Affairs, witnesses of marriage as well as employees of Office of Religious Affairs and not many who drove, only parents plus one-two brothers or neighbours. The causative factors are pornography that is easily accessible to teenagers, free association that violates religious norms that lead to pregnancy and lack of parental attention and lack of religious knowledge. The motive of underage marriage, because the bride to be has become pregnant, for religious reasons that are to get legal ratification, in terms of socio-cultural to save the good name of the parents, the reason economy parental responsibility is reduced. The impact of underage marriage on parents is seen from the aspect of religion formally can be fulfilled and avoided sin and

\footnotetext{
${ }^{7}$ Marmiati Mawardi, 'Problematika Perkawinan Di Bawah Umur', Jurnal Analisa, 19.2 (2012), 201.

${ }^{8}$ Libertus Jehani, Perkawinan Apa Resiko Dan Hukumanya, Jakarta: Niaga Swadaya, 2008, XXVII.
} 
adultery. The status of the baby being conceived is clear, the burden of the parent is reduced because there is already a responsible child.

Socially the parent is detached from the shame he has endured and his good name can be corrected. Economically, the responsibility increases because the child's economy is not yet established, especially for women because after marriage their children live together. For underage married couples are prone to disputes because psychologically and economically most are not yet established. Society considers underage marriage because it is forced, the family becomes ashamed, harms the parents, is psychically unprepared, still childish and economically not yet established so vulnerable to quarrels and can proceed to divorce.

Then the journal about early marriage and its influence on families in Sumenep Regency, East Java, in the study discussed about economic factors is reduce the burden of the family, the factor of self will to feel already in love, educational factors such as lack of knowledge of parents and children, family factors that are parents find a match for their children, and customary factors. Problems experienced by young married couples such as the selfishness between the couple itself, the occurrence of quarrels, squabbles, clashes between husbands and wives that if this continues can have an impact on divorce that is not through the judiciary due to their marriage under the hands / series. And the problem that arises is not only felt by the young married couple but also affects the parents of both parties because if the marriage between their children is smooth then both their parents will feel happy and happy. And the problem that arises is not only felt by the young married couple but also affects the parents of both parties because if the marriage between their children is smooth then both their parents will feel happy and happy. But if the marriage of their children fails, they will feel sad and disappointed about the condition of their children's household. From the failure of the marriage of his children did not close the possibility of friendship between the families will be severed.

Departing from previous research, it is considered necessary to conduct further assessment of the dispensation of underage marriage. If in a society, the majority of the population is underage and seems to be considered a natural thing, it will feel difficult to follow the mechanisms set, so this pattern of marriage is almost a habit. Therefore, it is feared that there are measures that are not justified. Because it is 
closely related to the effectiveness of the enactment of this Marriage Law, especially in terms of regulation of marriage age restrictions in the community. In the Marriage Act, in addition to regulating the lowest age limit, it is also regulated regarding the chance of deviation of the lowest age limit in the marriage. By giving leeway to prospective spouses who have not reached the lowest age limit specified, through dispensation provided by the court.

\section{Research methods}

The research method used is normative-empirical legal research, namely legal research that combines normative legal research and social/empirical legal research. In this type of research, the researcher conducts research by combining the two types of natural disasters on top of a study. ${ }^{9}$ The research method is supported by a conceptual approach, a type of approach in legal research that provides an analytical perspective on problems in legal research, seen from the legal aspects and concepts behind it, can also be seen from the values contained in the seeding of a rule related to the concept. used.

\section{ANALYSIS AND DISCUSSION}

\section{A. Legal Basis For Judges In Granting Applications For Marriage Dispensation}

Informing a family, maturity of the soul is certainly the main thing in marriage in order to be a good leader or advisor in a family. While in this case it is feared that there will be vulnerable damage in the household due to an emotional soul that is not mature enough, so it is vulnerable to divorce. Where in Islam divorce is an act that is allowed but deeply hated by Allah. ${ }^{10}$

Marriage in Islam, not only means the existence of institutions that allow a legal sexual relationship, but there is an aspect of universal law in the social institutional system that is very important because in society there are various groups and traditions with various interests of each, so there must be a public order in it. The

\footnotetext{
${ }^{9}$ Syahruddin Nawi, Penelitian Hukum Nomorrmatif Versus Penelitian Hukum Empiris, 5th edn (Makassar: PT.Umitoha Ukhuwah Grafika, 2017).

${ }^{10}$ Sabrianto Mochamad Samsukadi, 'Pertimbangan Hakim Dalam Mengabulkan Permohonan Dispensasi Kawin Anak Di Bawah Umur Berdasarkan Uu No. 1 Tahun 1974 Di Pengadilan Agama Kabupaten Madiun', 2017, 2, 195-216.
} 
order to perform marriage does not limit the age of a person to perform marriage but is emphasized about the need for one's maturity to be able to perform marriage. ${ }^{11}$

Regarding the Policy of judges is certainly closely related to the Politics of Law where the Politics of Law is a policy on the Law to be enforced, in this case, it could be the creation of new laws or the replacement of existing laws aimed at achieving a state goal. ${ }^{12}$ The politics of the law intended here is a form of a statement issued by the ruler of the state relating to the applicable law in a particular region, and where the law

Dispensation itself is a Political Law issued by the Judge on the basis of judicial power owned by the judge. The judge created a new rule allowing the marriage of minors, with inclusion for certain reasons. ${ }^{13}$ In other words, a marital dispensation is a request for dispensation for prospective brides who have not met the minimum age of marriage. A marriage dispensation letter from the local Religious Court is mandatory if either the bride to be or both have not met the marriage age limit. $^{14}$

Simply put, a marital dispensation is a leniency given by the Court of Religion to prospective Islamic husbands and wives who have not reached the age limit in conducting marriage, which must be requested to the Court of Religion. The dispensation of underage marriage is not immediately possible for any reason. Many factors behind the determination of marriage dispensation underage are it factors from the applicant or, from the consideration of the judge himself as the giver of marriage dispensation underage.

The basis used by the judge in granting the dispensation of the marriage age, namely Article 7 paragraph (2) of Law Number 1 of 1974 on Marriage. The Court of Religion is an institution that has the authority to handle applications for the dispensation of underage marriages. In the application for marital dispensation, the judge always lists Article 7 paragraph (2) of Law Number 1 of 1974 on Marriage, which is the legitimacy for judges who have been regulated in the Law. In Article 7

${ }^{11}$ Siskawati Thaib, 'Perkawinan Dibawah Umur (Ditinjau Dari Hukum Islam Dan UndangUndang Nomor 1 Tahun 1974)', Lex Privatum, 5.48-56 (2017).

${ }_{12}$ Moh. Mahfud MD, Politik Hukum Di Indonesia (Jakarta: Rajawali Pres, 2010).

13 Titania Elisa; Westra Ginting I Ketut, 'Perkawinan Anak Di Bawah Umur Di Lihat Dari Perspektif Hukum Pidana', Kertha Wicara : Journal IImu Hukum, Vol. 07, No. 03, Mei 2018, 2018, 115.

${ }^{14}$ Munadhiroh Mudadhiroh, 'Kajian Hukum Terhadap Permohonan Dispensasi Kawin Pada Perempuan Di Bawah Umur Di Pengadilan Agama Semarang (Studi Kesehatan Reproduksi)', Jurnal Idea Hukum, 2.1 (2016) <Https://Doi.Org/10.20884/1.Jih.2016.2.1.26>. 
paragraph (2) it is stated that deviations to the provisions of paragraph (1) concerning the minimum age limit for marriage, may request dispensation to the Court of Religion or other officials appointed by both parents of the male and female parties. $^{15}$

Therefore, people who believe in and believe in the norms and culture that live in society, certainly will not be affected by the new rule of law, even in the form of laws or in other regulations. ${ }^{16}$ If this condition is allowed and continues, then of course there will be more inequalities in the practice of state law, and in many ways that will have a negative impact.

With the Government regulation of the Republic of Indonesia Number 9 of 1975 concerning the implementation of Law Number 1 of 1974 concerning marriage chapter 2 Article 6 Number 2 (c) written permission/court permission as referred to in Article 6 paragraph (2), (3), (4) and (5) law, if one of the prospective brides or both have not reached the age of 21 years. ${ }^{17}$ Then Article 2 of marriage law Number 1 of 1974 , states marriage is valid if done according to the laws of each religion and its beliefs. $^{18}$

Furthermore, judges generally place emphasis on the principle of legal certainty, which is more nuanced in the creation of order and order in society, and on the principle of justice, where judges must always consider the living and existing laws in society, consisting of convention habits and provisions. In weighing the verdict, the panel of judges must still describe it all, while the judge chooses to uphold the principle of justice for example, as the basis for delivering the verdict.

The emphasises on applying the principle of benefit are more nuanced to the economic aspects, on the basis that the law exists for man. So that the purpose of the law should be useful to many people. In the application for marital dispensation, the panel of judges put forward the principle of legal benefit seen from the point of view of legal sociology, which aims to make the law focused on the benefit.

The principle of the use of the law is more looking at the human being and not the other way around. A panel of judges grants parents who apply for a dispensation

\footnotetext{
${ }_{10}^{15}$ Undang-Undang Nomor 1 Tahun 1974 Tentang Perkawinan, 1974, Pp. 1-15.

${ }^{16}$ Jaenal Arifin, Peradilan Agama Dalam Bingkai Reformasi Hukum Di Indonesia (Jakarta: Kencana Prenada Media Group, 2008).

${ }^{17}$ Abdurrahman, Kompilasi Hokum Islam Di Indonesia (Jakarta: Akademika Pressindo, 2010).

${ }^{18}$ Amir Syarifuddin, 'Hukum Perkawinan Islam Di Indonesia: Antara Fiqh Munakahat Dan Undang-Undang Perkawinan' (Jakarta: Kencana, 2006), p. 28.
} 
to the Court of Religion because it is considered to be of greater benefit than not being granted. As in the determination of the verdict, where the applicant is the parent of a 15-year-old girl. In addition, the applicant plan to hold a marriage but the Office of Religious Affairs refused to marry, under the pretext of not being old enough under Law Number 1 of 1974 on Marriage, which is not yet reached the age of 16 years. The applicant's daughter is rumoured to have been dating a man who has known each other and has long loved each other. The applicant's child is physically and legally mature and for the applicant's daughter with her future husband, there is no obstacle to being able to marry.

\section{B. Basic and Consideration of Judges}

When the judge will make a decision, then the panel will always try to make the verdict delivered as much as possible can be received well by the community. The judge will be relieved if he can satisfy all parties with his verdict. In order for the verdict to be accepted by the other party, the panel of judges must convince the other party with the reasons or considerations that the verdict is appropriate and correct.

In the process of legal formation, by the judge, it is impossible to directly apply the rule of law to concrete events. Concrete events are first used as legal events so that the rule of law can be applied. The basis of the Volunteer's lawsuit is a civil matter which is then filed into the form of an application signed by the applicant and addressed to the court, where the matter raised is more of a unilateral interest only. Thus, what the applicant requested does not come into contact with the rights and interests of others.

Considerations in deciding the case by the judge mejelis, in an effort to apply the rule of law to the event based on the rules or with certain methods used, in order to list the basis of consideration of the event is carried out relevantly and also appropriately according to the law so that what is produced later, obtained from the process of the case can be accepted and accounted for in the community especially in the world of legal science.

The judge excavated the testimony of the witnesses linked to the evidence of the petitioner's application, and then at that time, the panel of judges judged that the applicant's son was considered worthy to be mated to avoid unwanted things in the 
day's study because the two were both like and love each other. In this case, the judge has no power to refuse to grant marriage dispensation, because it is feared that if the application is rejected, the consequences could be greater. The panel of judges sought to avoid Mafsadah, and put Maslahah first so that the two brides to be should be married immediately.

The relationship between the two children who are said to have liked each other and loved each other is feared that one day it will go down the wrong path. The desire of parents who already want their children to be married immediately, and children who already have a high desire to build a household, but are constrained because of the age limit according to the Marriage Law is not old enough, even though both parents have approved their relationship.

With the granting of marital dispensation by the Court of Religion, the validity of the status of their marriage becomes valid before the law and in the eyes of the public of course. To avoid unwanted things, the judge is looking at the law should consider the legal benefits in granting the application for marital age dispensation. Based on the dispensation determination, the judge is not bound by positive laws. In other words, the law of judging the verdict in accordance with the application is the determination, which is commonly referred to as Beschikking in a broader sense. For the case of marital dispensation is actually only to be able to obtain the rights of the applicant, so that all that is needed is witness statements from parties who know the applicant's condition.

The determination of the verdict, the panel of judges refers not only to the Marriage Act regarding the age limit, but the judge is progressive in which the judge puts the greater human interest over-interpreting the law itself from the point of logic and regulation. In some cases, the panel of judges is not authorized to reject the applicant's application because the judge prioritizes the legal benefits for community development and prioritizes the issue of benefit for the public interest. It is feared that there will be more mudharat obtained if the application for marital dispensation is rejected.

In handling the case the judge embraced the Interessenjurisprudens (Freirechtslehre), which argues that the law is clearly incomplete. Legislation is not the only source of law, while judges have the widest freedom to make legal 
discoveries. So that the panel of judges not only apply the legislation, but also expand, and form the rules in the judge's decision.

The legal basis for the panel of judges in granting an application for marital dispensation, among others, refers to:

i. Provision of Article 6 paragraph (1) and Article 7 paragraph (1) (2) of Law Number 1 of 1974. In order for the marriage to form an eternal and happy family, and in accordance with human rights, both parties who will hold the marriage, without any pressure or coercion from any party, must approve the marriage. Then in the provisions of Article 7 paragraph (1) and paragraph (2) of Law Number 1 of 1974, which means, if one or both brides do not meet the provisions of Article 7 paragraph (1) to perform a marriage, then the guardian must apply for a marital dispensation to the Court of Religion. ${ }^{19}$

ii. Article 15 paragraph (1) and Article 53 of the Compilation of Islamic Law, according to the provisions in Article 15 of the Compilation of Islamic Law, have clearly restricted the age of prospective brides (prospective spouses), in accordance with the law above which is Article 7 paragraph (1) of the Marriage Law Number 1 of 1974. However, the rule of law does not detail the reasons for applying for marriage dispensation law. ${ }^{20}$

iii. Article 39 to Article 44 of the Compilation of Islamic Law, as in the application for dispensation that has been handled by the judge, where the judge considers that from the legal facts outlined above, the panel of judges concluded that the applicant's child with her husband to be has both fulfilled the requirements of marriage and between the applicant's child and her future husband also can not obstruct the conduct of marriage as outlined in Article 39 to Article 44 compilation of Islamic law. ${ }^{21}$

iv. Law Number 23 of 2002 on Child Protection, which states that parents are obliged and responsible to prevent marriage at the age of children, is intended as a form of early emphasis on parents who control children to sexually exploit children as referred to by Article 13 letter (b) of Law Number 23 of 2002 on Child Protection. In addition, Article 6 of Law

\footnotetext{
${ }^{19}$ Undang-Undang Nomor 1 Tahun 1974 Tentang Perkawinan.

${ }^{20}$ Kompilasi Hukum Islam, 1975.

${ }^{21}$ Kompilasi Hukum Islam.
} 
Number 23 of 2002 on Child Protection also states that Every child has the right to perform worship according to his/her religion, conduct thought processes, and express his wishes according to his or her level of intelligence and age, but that is inseparable from the guidance of parents. ${ }^{22}$

Then in terms of worship, Islam has categorized marriage as worship, which is a fundamental right or basic right of every human being, and the worship can be carried out if the terms and conditions as in the legislation have been met.

v. Rules, in addition to the provisions of the Articles, mentioned above, the panel of judges also uses another legal basis, namely the rules in granting marriage dispensation requests for minors. This is appropriate because every determination of the dispensation of underage marriage is always listed fiqhiyyah rules, which are subsequently taken over as the opinion of the panel of judges, which means rejecting the danger of taking precedence over good.

vi. The judge considered that granting the request for dispensation of underage marriage could avoid damages so that the marriage must be done immediately so that in the future nothing will happen that is not wanted. The panel of judges based on the fiqhiyyah rules of law so as not to cause Mafsadat for both candidates and their entire families. So that the situation should not be allowed and must be ended immediately, as a form of legal protection to the two brides and their entire families.

In settling the verdict, the panel of judges must have legal considerations, such as consideration of the events obtained by the witnesses. After understanding the event or sitting the case, then in this case the panel of judges can adjust it to the legislation governing the case of marriage dispensation application. So that through the adjustment between the applicable laws to the reality that occurs, there will be a determination that meets the sense of justice for the parties concerned.

The results showed that the factors that influenced the judge's consideration in granting the application for dispensation of underage marriage, generally because:

${ }^{22}$ Undang-Undang Nomor 23 Tahun 2002 Tentang Perlindungan Anak, 2002, pp. 4-8. 
i. As a result of pre-marital pregnancy is reviewed from the aspect of maqashid syari'ah in terms of maslaha as a means to protect human rights prefer the maintenance of offspring and nasab children (hifzh al-nas), while in terms of mafsadat religious maintenance (hifz al-din) is not achieved, there has been a violation of syari'at in Islam which makes the Compilation of Islamic Law Article 53 as the legality of pregnant marriage due to adultery. ${ }^{23}$ In urgent circumstances, a judge may grant the dispensation of underage marriage.

ii. Because of the benefit and harm, if the application for dispensation of underage marriage is not granted, then the impact will be very large, this is where the role of judges and at the same time the law is needed by the community in providing convenience and the best way out of the problems that occur in the community itself, because if it is not granted it will have an impact on the pressures and gossip of the people around because it is not able to educate their children.

iii. Family Economic Factors, generally the reason the applicant's parents feel that if the child is married to another man, it will be very helpful for the economy of his parents. And

iv. The educational factor is still low, so marriage at a very young age is considered something taboo.

\section{Conclusion}

About the legal basis of judges in granting applications for the dispensation of underage marriages, namely Law Number 1 of 1974, Compilation of Islamic Law, Law Number 23 of 2002, and fiqqiyah rules. Then the factors that influence the consideration of the panel of judges include pregnant out of wedlock, for the benefit and harm, economic factors, and education that is still relatively low so that the phenomenon of early marriage is still very felt. often found especially in areas where the majority of education awareness levels are still relatively low.

${ }^{23}$ Rizkiyah Hasanah, 'Penetapan Dispensasi Kawin Akibat Hamil Pra-Nikah Ditinjau Dari Aspek Maqashid Syari'ah', Aktualita (Jurnal Hukum), 1.1 (2018), 295-311 <https://doi.org/https://doi.org/10.29313/aktualita.v111.3724>. 


\section{Reference List}

Abdurrahman, Kompilasi Hukum Islam Di Indonesia (Jakarta: Akademika Pressindo, 2010)

Arifin, Jaenal, Peradilan Agama Dalam Bingkai Reformasi Hukum Di Indonesia (Jkarta: Kencana Prenada Media Group, 2008)

Ginting I Ketut, Titania Elisa; Westra, 'Perkawinan Anak Di Bawah Umur Di Lihat Dari Perspektif Hukum Pidana', Kertha Wicara: Journal IImu Hukum, Vol. 07, No. 03, Mei 2018, 2018, 1-15

Hasanah, Rizkiyah, 'Penetapan Dispensasi Kawin Akibat Hamil Pra-Nikah Ditinjau Dari Aspek Maqashid Syari'ah', Aktualita (Jurnal Hukum), 1.1 (2018), 295-311 <Https://Doi.Org/Https://Doi.Org/10.29313/Aktualita.V1i1.3724>

Jehani, Libertus, Perkawinan Apa Resiko Dan Hukumanya, Jakarta: Niaga Swadaya, 2008, XXVII

Kompilasi Hukum Islam, 1975

Mahfudin, A Dan; Khoirotul Waqi'ah, 'Pernikahan Dini Dan Pengaruhnya Terhadap Keluarga Di Kabupaten Sumenep Jawa Timur', Hukum Keluarga Islam, 1.April (2016), 33-49 <Http://Journal.Unipdu.Ac.Id:8080/Index.Php/Jhki/Article/View/608>

Mawardi, Marmiati, 'Problematika Perkawinan Di Bawah Umur', Jurnal Analisa, 19.2 (2012), 201

Md, Moh. Mahfud, Politik Hukum Di Indonesia (Jakarta: Rajawali Pres, 2010)

Mochamad Samsukadi, Sabrianto, 'Pertimbangan Hakim Dalam Mengabulkan Permohonan Dispensasi Kawin Anak Di Bawah Umur Berdasarkan Uu No. 1 Tahun 1974 Di Pengadilan Agama Kabupaten Madiun', 2017, 2, 195-216

Mudadhiroh, Munadhiroh, 'Kajian Hukum Terhadap Permohonan Dispensasi Kawin Pada Perempuan Di Bawah Umur Di Pengadilan Agama Semarang (Studi Kesehatan Reproduksi)', Jurnal Idea Hukum, 2.1 (2016) <Https://Doi.Org/10.20884/1.Jih.2016.2.1.26>

Nawi, Syahruddin, Penelitian Hukum Normatif Versus Penelitian Hukum Empiris, 5th (Makassar: Pt.Umitoha Ukhuwah Grafika, 2017)

Rifiani, Dwi, 'Pernikahan Dini Dalam Perspektif Hukum Islam', Journal De Jure, 3.2 (2011) <Https://Doi.Org/10.18860/J-Fsh.V3i2.2144>

Siskawati Thaib, 'Perkawinan Dibawah Umur (Ditinjau Dari Hukum Islam Dan Undang-Undang Nomor 1 Tahun 1974)', Lex Privatum, 5.48-56 (2017) 
Syahril, Muh Akbar Fhad, 'The Effectiveness Of The Annulment Of Marriage Due To Impersonation And Its Legal Consequence', losr Journal Of Humanities And Social Science (losr-Jhss, 23.2 (2018), 2279-0845 $<$ Https://Doi.Org/10.9790/0837-2302023944>

Syarifuddin, Amir, Garis-Garis Besar Figh, Jakarta (Predana Media, 2005)

- 'Hukum Perkawinan Islam Di Indonesia: Antara Fiqh Munakahat Dan Undang-Undang Perkawinan' (Jakarta: Kencana, 2006), P. 28

—_, Hukum Perkawinan Islam Di Indonesia, 2006

Umar Said, Hukum Islam Di Indonesia Tentang Perkawinan (Surabaya: Cempaka, 2000)

Undang-Undang Nomor 1 Tahun 1974 Tentang Perkawinan, 1974, Pp. 1-15

Undang-Undang Nomor 23 Tahun 2002 Tentang Perlindungan Anak, 2002, Pp. 48 